\title{
What future for primates? Conservation struggles in the forests of Cross River State, Nigeria
}

\author{
Torsten Krause $^{1}$ (D) $\cdot$ Tobias Nielsen $^{2} \cdot$ Laura Guia-Diaz $^{3} \cdot$ Veiko Lehsten $^{4} \cdot$ Ola Olsson $^{3} \cdot$ Fariborz Zelli $^{2}$
}

Received: 17 July 2018 / Accepted: 24 January 2019 / Published online: 25 February 2019

(c) The Author(s) 2019

\begin{abstract}
While deforestation and forest degradation have gained attention in recent years not least at the UN climate negotiations, a third "de", i.e., defaunation, has to a great extent been overlooked. Human-induced faunal loss does not only reduce tree species diversity, but also significantly erodes key ecosystem services and functions and further disadvantages local communities. In this article, we analyze these impacts, and the associated multi-level governance gaps, through a case study of Nigeria's Cross River State and make suggestions for more encompassing conservation approaches that take defaunation into account. To this end, we analyze the interplay between current forest governance and REDD+ in Cross River State and local hunting of forest fauna. Drawing on Ostrom's social-ecological systems framework and a mixed-methods approach, we identify shortcomings and gaps of international and domestic forest governance, for instance, the ongoing expansion of agriculture in forest areas, a lack of collective action on forest fauna conservation at the local level, as well as conflicts amongst key actors at the sub-national level. Current REDD+ governance in Cross River State largely fails to address fauna loss and local hunting practices, but also affect allocation and access of environmental benefits and burdens for local people.
\end{abstract}

Keywords Forest governance $\cdot$ REDD $+\cdot$ Forest biodiversity $\cdot$ Hunting $\cdot$ Social-ecological systems

\section{Introduction}

Forests feature prominently at the global political agenda since a global mechanism to address emissions from deforestation and forest degradation (REDD) was proposed to the UNFCCC in 2005. Subsequently, in 2008, the mechanism was enlarged to include the conservation of forest carbon stocks, the sustainable management of forests, and enhancement of forest carbon stocks, symbolized by the addition of the '+' (Skutsch and Van Laake 2008; Angelsen et al. 2009; Strassburg et al. 2009; Corbera and Schroeder 2011).

Handled by: Fabrice Renaud, University of Glasgow, Germany.

Torsten Krause

torsten.krause@lucsus.lu.se

1 Lund University Centre for Sustainability Studies, P.O. Box 170, 22270 Lund, Sweden

2 Department of Political Science, Lund University, Lund, Sweden

3 Department of Biology, Lund University, Lund, Sweden

4 Department of Physical Geography and Ecosystem Science, Lund University, Lund, Sweden
Since then, there has been an increasing number of concrete REDD+ proposals and many potential and actual implications of these have found their way into scholarly and political debates (Krause and Nielsen 2014; Hinsley et al. 2015; Baccini et al. 2017; Boissière et al. 2017).

However, REDD+ has also been criticized as being reductionist, omitting the fact that forests are complex social-ecological systems (Messier et al. 2015). Defaunation, that is the loss of forest fauna as a consequence of human forest-related activities, primarily hunting, has been largely overlooked in REDD+ discussions and does not feature in the Warsaw Framework (UNFCCC 2013) nor in subsequent REDD+ related decisions (UNFCCC 2016), even though it has major implications for forests (Hinsley et al. 2015).

Human-induced faunal loss reduces tree species diversity in tropical forest (Muller-Landau 2007; Effiom et al. 2013; Galetti et al. 2013; Bello et al. 2015; Benítez-López et al. 2017; Culot et al. 2017) and may negatively affect carbon storage in tropical forests (Brodie 2016, 2018; Peres et al. 2016). Furthermore, defaunation also erodes key ecosystem functions and services and further disadvantages local communities who often depend on forest resources and wild 
meat (Nasi et al. 2011; van Vliet et al. 2015; Nielsen et al. 2018).

Therefore, studying the drivers of defaunation, particularly hunting and the local norms, rules and patterns of behavior around hunting, is critical for more robustly understanding forest ecosystems. To do this, the REDD+ strategy development and demonstration activities in Cross River State (CRS) in Nigeria are used to assess best practices and lessons learned that could be used to roll out REDD+ in other states across the country. Furthermore, scrutinizing local hunting practices is also important with regard to achieving the biodiversity co-benefit objectives and social equity in REDD+. Our findings point to potential implementation gaps of REDD+ in Cross River State and on biodiversity conservation in tropical forests in general.

Similar to other sub-Saharan countries, Nigeria experiences substantial population growth, which likely exacerbates demand for arable land and forest resources. CRS is expected to increase strongly in population until 2050 ranging from a tripling to an eightfold increase compared to the year 2000 (Boke-Olén et al. 2017). While this increase will mainly be in urban areas, the associated increase in demand for land will put additional pressure on protected areas and remaining forests, both in terms of hunting pressure as well as farm encroachment. Given that only a small proportion of Nigeria's area is still forested, there needs to be decisive action now to ensure the survival of the remaining forest fragments as habitats suitable for animals, and as a supplier of resources for people.

We analyze defaunation in the context of forest governance and REDD+ in Nigeria's Cross River State and present findings from a case study looking at local institutions in a common pool resource system. Using Ostrom's socialecological systems (SES) approach (Ostrom 2009), our findings are structured along the eight design principles of common pool resource (CPR) systems (Ostrom 1990). We use Ostrom's SES framework as benchmarks to show how an interplay of factors across scales shapes the extent to which the community in question aspires to a more sustainable use of wildlife and forests, and the norms and rules that shape the behavior of the resource users. We also place a special emphasis on local hunting of forest fauna and its embeddedness in the multi-level legal-political context that shapes forest governance in CRS.

\section{Biodiversity conservation and REDD+ in Nigeria and Cross River State}

Since colonization in the mid-19th century, Nigeria has lost more than $90 \%$ of its forest cover (Enuoh and Bisong 2015). Deforestation in Nigeria continues and the reported annual rate between 2010 and 2015 was 5\%, one of the highest in the world (FAO 2016). In addition, hunting in Nigeria is often driven by cash income, leading to a decline in wildlife through overexploitation by local people and professional hunters, but also due to forest clearing and habitat loss (Nielsen et al. 2018). Nigeria has actively pursued REDD+ as a strategy for building stronger forest institutions since 2009 and became a UN-REDD partner country in 2010 (Maukonen et al. 2017).

Our case study area is located in Cross River State in southeast Nigeria along the border to Cameroon. CRS contains the last sizeable, but fragmented and isolated tropical forests in Nigeria (Ezebilo and Mattsson 2010), and are part of the Guinean Forests of West Africa global biodiversity hotspot (Myers et al. 2000). These forests are among the last habitats for the rarest western gorilla subspecies, the critically endangered Cross-River gorilla (Gorilla gorilla diehli) (Bergl et al. 2016), with a total population estimated to be less than 300 individuals (Dunn et al. 2014). The remaining forests are also crucial for the survival of a range of other endangered species, for instance the critically endangered drills (Mandrillus leucophaeus) and Nigeria-Cameroon chimpanzees (Pan troglodytes ellioti) (The IUCN Red List of Threatened Species 2017). The ongoing illegal hunting and habitat loss continues to negatively affect these species (Dunn et al. 2014; Thalmann et al. 2011).

The ongoing expansion of urban areas and agricultural land, together with new infrastructure and road building projects further reduces the area and quality of forest habitats (Mahmoud et al. 2017). Albeit road construction may facilitate access to markets to purchase animal protein, easier access into remote areas puts additional pressures on forests facilitating timber extraction and hunting (Laurance et al. 2017).

Deforestation in CRS is rampant largely due to pressure from agriculture, industry, human settlement and infrastructure, and the estimated forest loss in Cross River State was 49,100 ha from $2001-2016$, or a $3.9 \%$ decrease (at $30 \%$ canopy cover), with the highest losses recorded after 2013 (GFW 2018). Since 2012, REDD+ in Nigeria is piloted in CRS. The program has received financial support from the UN-REDD program (US\$ 4 million) and the World Bank's Forest Carbon Partnership Facility (US\$ 3.6 million) to build and strengthen forest governance; it now hosts several REDD+ pilot schemes (Nigeria 2017; UN-REDD 2015). Additional support is provided by the California-led Governors' Climate and Forests Task Force.

The REDD+ pilot sites in the study area encompasses the Mbe Mountains community conservancy and the area around the Afi Mountain Wildlife Sanctuary (UN-REDD 2015) (Fig. 1). We conducted our study in Abo Ebam community (Fig. 1), which has a relatively large community forest bordering the Afi River Forest Reserve adjacent to the Afi Mountain Wildlife Sanctuary. We selected this 


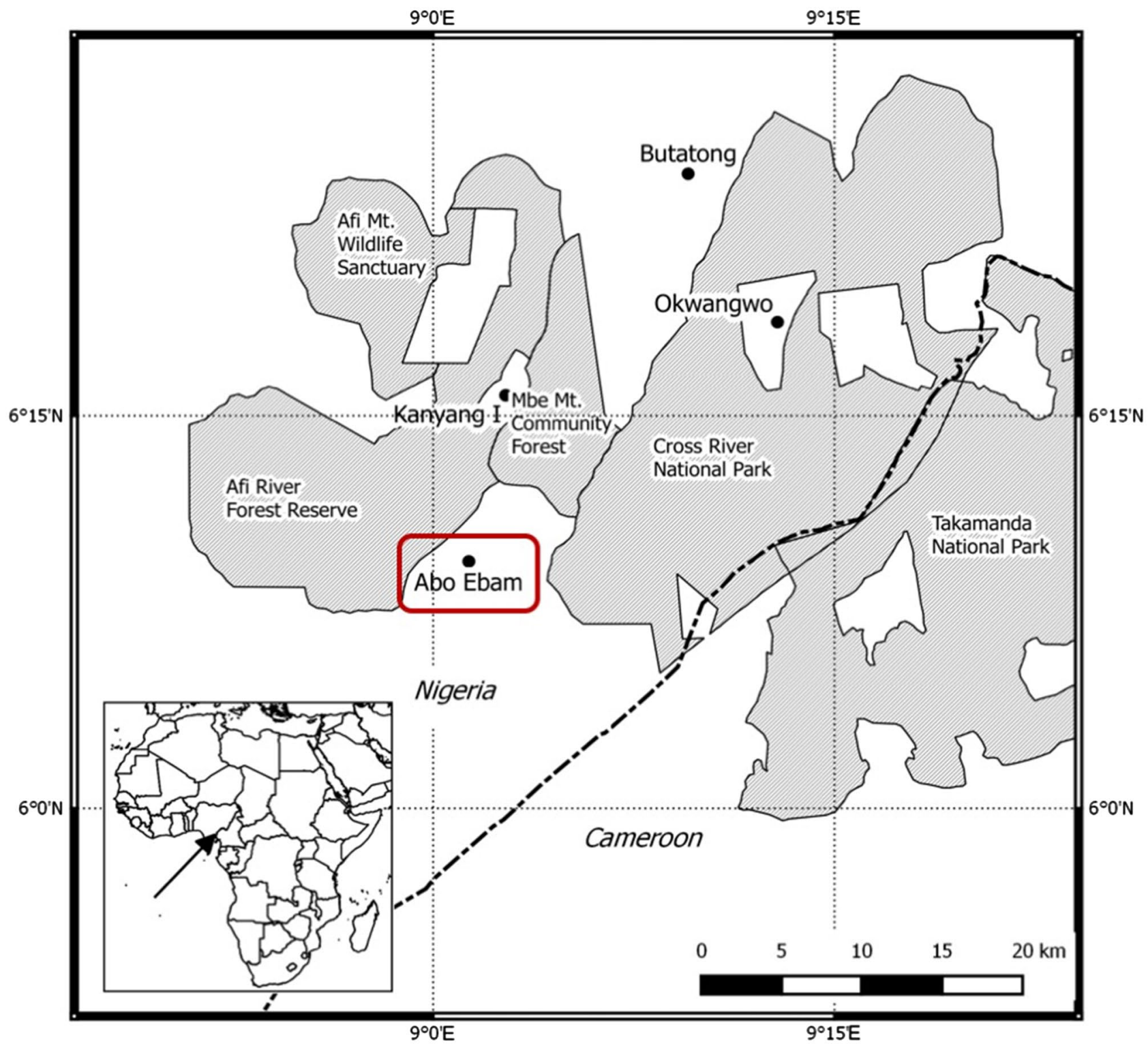

Fig. 1 Location of case study site in Nigeria's Cross River State (red square) and protected areas (in gray). Map polygons downloaded from World Database of Protected Areas (WDPA). REDD+ in CRS

community because of prior established relationships from previous research projects (Andersson Djurfeldt et al. 2017), their previous involvement in REDD+ workshops, and since the community forest borders the Afi River forest reserve and the Afi Mountain wildlife sanctuary, a known habitat for the three endangered species of primates (Dunn et al. 2014). Hunting is a very common activity in the area and combined with habitat loss and fragmentation, it is an increasing threat to many species, particularly the CrossRiver gorilla (Effiom et al. 2013; Dunn et al. 2014; Bergl et al. 2016; Imong et al. 2016). includes the Afi Mt. Wildlife Sanctuary, the Mbe Mt. Community Forest and the Afi River Forest Reserve

The CRS forestry commission has substantial rights under CRS state forest law, including the right to issue permits for the use of forest products (e.g., timber, non-timber forest products), prohibiting the harvesting of plants and animal species, or declaring any forest area a protected forest when there is overriding public interest or for ecological reasons (CRS 2010). Entering a wildlife sanctuary is prohibited without a permit and hunting inside a sanctuary is not allowed (CRS 2010). Furthermore, the forestry commission may also make amendments to the law and community by-laws to protect animals (CRS 2010). Forest reserves are 
managed by the forestry commission in collaboration with local communities and the harvest of forest produce is only allowed when approved by the commission. Community forests are subject to customary law and communities have exclusive user rights (CRS 2010). This means that community forests can be used by the community members, for example, for hunting, provided endangered species are not extracted (Andersson Djurfeldt et al. 2017).

\section{Analytical framework}

We analyze defaunation in the context of forest governance and REDD+ in CRS. We examine local institutions, i.e., local norms, formal and informal rules and patterns of behavior (North 1990; Ostrom 1999; Williamson 2000; Gibson et al. 2005), in a community forest that shares several characteristics of a CPR system (Ostrom et al. 1999). Access to and extraction of resources from the forest, such as wildlife, is open to community members with very few limitations in quantity of extractions, and the resources are typically non-excludable and rivalrous.

Drawing on Ostrom's original SES framework, we identify and analyze relationships among multiple levels at different spatial scales (Ostrom 2009). The explorative application of the SES framework helps us to place our findings in a wider multi-level legal and political context, by particularly focusing on: the substantial changes that forest governance underwent through the development of REDD+ in CRS, communities' access, and use of forest resources, and the current discourse around forests (Asiyanbi 2016; Matakala 2016; Asiyanbi et al. 2017; Maukonen et al. 2017).

More concretely, we concentrate on the eight design principles for CPR that characterize robust SESs and CPR institutions - and that integrate and combine some of these factors (Anderies et al. 2004). Seven of these design principles address properties that the systems and the institutions therein should exhibit (Ostrom 1990: 90):

1. clearly defined boundaries for users and for the resource system (community forest and wildlife);

2. congruence between costs and benefits and between conservation rules and local social and governance conditions;

3. collective-choice arrangements, i.e., inclusion of most individuals affected by certain rules into the group that can modify them;

4. active monitoring of bio-physical conditions and user behavior, with monitors either being the users themselves or actors accountable to those users;

5. graduated sanctions depending on the seriousness and context of the offense;
6. conflict-resolution mechanisms to which users and officials have rapid and low-cost access;

7. minimal recognition of the rights of users to organize, including long-term tenure rights to the resource.

The remaining design principle accounts for the wider embeddedness of the resource system under scrutiny corresponding to our objective to analyze the interplay of local institutions, norms and practices relevant to the hunting of forest fauna within the domestic and international context of forest governance and REDD+:

8. nested enterprises, i.e., appropriation, provision, monitoring, enforcement, conflict resolution, and governance activities are organized in multiple layers (Ostrom 1990).

These eight principles serve as benchmarks for our analysis. In our exploration of these principles, we will discuss to what extent these benchmarks are met or missed in a community resource system in the Boki local government area in northern CRS.

\section{Materials and methods}

We collected primary data through interviews with local community members, forestry experts and representatives of public authorities. Secondary data were collected from relevant peer-reviewed literature, official REDD+ reports and relevant national and state laws. We also present field observations collected during our visit to CRS in November 2016.

Primary data were collected through semi-structured interviews with 21 individual community members at the study site. Interviews with two representatives from NGOs actively working with primate conservation in CRS, three senior officials from the Forestry Commission, one representative from the Ministry of Climate and Forestry, one former member of CRS Anti-deforestation Task Force (ATF), and one CRS forestry expert were carried out in Calabar in English. The expert interviews centered around forest governance issues in CRS, hunting of forest fauna and current challenges in implementing REDD+.

The interviews with community members were conducted in English in the Boki local government area in northern CRS (see Fig. 1) during our stay in the community that lasted 8 days in November 2016. The selection of interviewees was carried out with the help of local assistants and interviews were conducted at the interviewees' residences to allow for a more private and comfortable setting for the interview. These individual interviews focused on local resource use, hunting practices and frequency of hunting, 
targeted animals, and local rules on forest and resource extraction. In addition, we carried out three narrative walks with community members through their farms and the community forest. These walks lasted $1-2 \mathrm{~h}$ each and allowed us to further insights and triangulate data about local land use practices, such as main subsistence and cash crops grown and the different forest resources that are being collected as well as how and where they are harvested. Thus, the narrative walks complemented our interview data with additional observations and we could ask targeted questions to better understand the dynamics of land and forest use as well as hunting practices in the community forest.

To address the principles seven (rights recognition) and eight (nested enterprises) in the wider context, we carried out a literature review and qualitative document analysis of REDD+ documents published by the Nigerian government and the national REDD+ authority, particularly with a focus on the extent to which hunting and biodiversity conservation features in these documents.

\section{Results}

In this section, we provide an overview of the 'resource systems', 'actors' involved in the use of the community forest, and types of 'governance', e.g., local norms and rules that govern resource extraction, some of which being contradictory.

\section{Resource system and actors}

The local resource system we focus on is the community forests where non-timber forest products (NTFPs), timber and wild meat are extracted and small-scale agriculture is carried out. The actors include village farmers and village hunters. Almost all the respondents collect NTFPs, such as fruits, nuts, food, and medicinal plants. These community forest resources are a common pool resource and constitute a principal contribution to local livelihoods that is open for everyone belonging to the respective village. Non-farm trees inside the community forest are collectively owned and the collection of fruit is based on a first-come first-serve basis (Sunderland 2001).

Most interviewees have their own farms where they grow a variety of subsistence crops, such as cassava and bananas, and cocoa as the main cash crop. In addition, hunting and the trapping of forest animals is an important source of food and carried out by the majority of respondents. While hunting with locally made shotguns is usually carried out by men, trapping of small game around farms, and the incidental collection of snails, tortoises or pangolins, is common amongst all the members of the community.
The majority of respondents did not mention any technical or financial barriers to hunting, trapping and collecting NTFPs.

"Now everyone can afford a gun or trap. Amount of hunting is higher now due to technical advance, same for farming. Bank loans make it possible to employ someone to clear the land" (57-year-old male respondent).

Interviewees mentioned that the number of primates and other wildlife decreased substantially over the past years and that other species are becoming increasingly rare.

“They are becoming extinct, you can't see wild animals anymore" (60-year-old male respondent).

Beyond hunting, one of the key drivers of this has been the rapid expansion of farm land.

"Our parents did not have big farms, but farms are now engulfing the forest" (46-year-old male respondent).

Respondents hunt in the community forest up to the border of, and occasionally inside, the Afi River Forest reserve, although they know that it is illegal. However, the importance of wild meat had fallen over time and is a minimal source of income nowadays (estimated at $6 \%$ of household income generated by selling meat from forest animals), compared to 10 years ago (Andersson Djurfeldt et al. 2017). However, hunting is still carried out widely; for the community studied $79 \%$ of all households engage in hunting (Andersson Djurfeldt et al. 2017) (Figs. 2, 3).

The role of wild caught meat in local diets in this region has changed over the past decade, and in this specific community has dropped from $87 \%$ of all meat consumed to $67 \%$ (Andersson Djurfeldt et al. 2017). Most of that meat is from porcupines, cane rats, duikers, wild pigs, and a few other

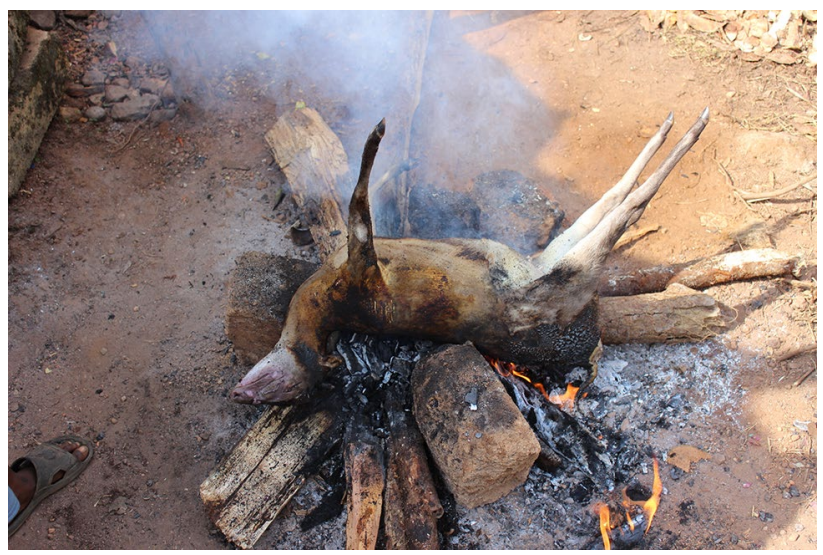

Fig. 2 Recently hunted duiker (Cephalophinae-listed in the 2010 CRS law no. 3) being prepared for food outside the local restaurant. photo by Torsten Krause 


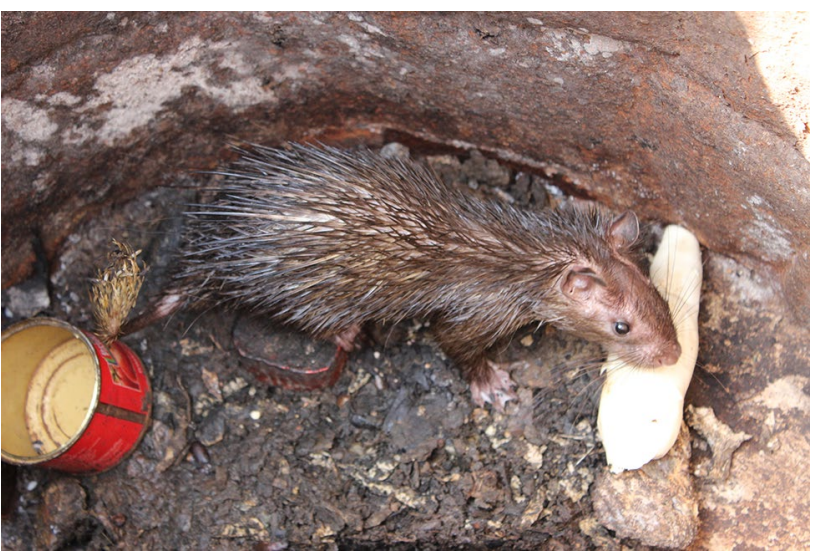

Fig. 3 Brush-tail porcupine (schedule 1 species in the Nigerian Endangered Species Act from 1985, not listed in the 2010 CRS law no. 3) captive and kept for later consumption. photo by Torsten Krause

species (Table 1). Although primate meat was less significant, it still constituted an important component of local diets, mainly due to taste preferences and cultural perception of it being of superior quality (Andersson Djurfeldt et al. 2017). Another important source of animal protein is fish, which are caught in local rivers or purchased.

Porcupine (Atherurus africanus), duikers (Cephalophinae spp.) and cane rats (Thryonomus swinderianus) are typically caught in traps. These species have also been reported to be the most commonly hunted species and represent an important part of local diets. Another species commonly trapped with wire snares in the area is the rock hyrax (Procavia capensis) (Dunn et al. 2014), although none of our interviewees mentioned this particular species. Many of the species that local respondents consumed are listed in the Nigerian Endangered Species Act prohibiting the hunting of these species (Nigeria FGo 1985).

Most interviewees stated that wildlife has decreased in the community forest over the past years. Particularly primates and other monkeys are much less abundant and harder to find than they used to be in the past.

"Until 2010 you could hear them [the chimps] beat their chests" (52-year-old male respondent).

Interviewees stated that chimpanzees and gorillas are almost never observed in the community forest and drills only on rare occasions when a group of this mobile species moves through the community forest. Another interviewee said that if you were to look for monkeys, one would have to go deep into the Afi Mountain Wildlife Sanctuary, where you can still find a population of Cross River gorillas (Bergl et al. 2012). While chimpanzees and gorillas tend to have marked and relatively fixed home ranges, drills are nomadic and move around in large groups. This makes the conservation of drills particularly difficult, as groups will frequently come into contact with people and farms during their movements through an area (Personal communication, conservation organization representative, November 2016).

\section{Types of governance: rules, norms, and belief systems governing hunting practices}

The interviews revealed a continuum of responses varying from valuing conservation to contesting conservation. Forests are perceived as inexhaustible by people and hunting

Table 1 Respondents most preferred bushmeat species and their legal status according to the *Nigerian Endangered Species Act from 1985 and the \#2010 Cross River State Law no. 3

\begin{tabular}{|c|c|c|c|}
\hline \multirow[t]{2}{*}{ Species/genus } & \multirow{2}{*}{$\begin{array}{l}\text { Respondents personal } \\
\text { consumption prefer- } \\
\text { ence }\end{array}$} & \multicolumn{2}{|l|}{ Classification of species } \\
\hline & & $\begin{array}{l}\text { National level-Nigerian Endan- } \\
\text { gered Species Act from } 1985 .\end{array}$ & $\begin{array}{l}\text { Regional level-Cross River State Law } \\
\text { No. } 3 \text { from } 2010\end{array}$ \\
\hline $\begin{array}{l}\text { Brush-tailed porcupine (Atherurus } \\
\text { africanus) }\end{array}$ & 16 & Listed & Not listed \\
\hline Duikers (Cephalophinae spp.) & 11 & Listed (Cephalophus Sylvicultor) & Six species of duikers listed \\
\hline Cane rat (Thryonomus swinderianus) & 8 & Not listed & Not listed \\
\hline Red river hog (Potamochoerus porcus) & 5 & Not listed & Not listed \\
\hline Bushbaby (Galago, Galago spp.) & 2 & Listed & Three species listed \\
\hline Monkeys (Cercopithecus spp.) & 2 & Listed & $\begin{array}{l}\text { All monkeys listed as fully protected } \\
\text { species }\end{array}$ \\
\hline $\begin{array}{l}\text { Pangolins-Uromanis tetradac- } \\
\text { tyla, Phataginus tricupsis, Smutsia } \\
\text { gigantean }\end{array}$ & 2 & All three species listed & $\begin{array}{l}\text { All three species listed as fully protected } \\
\text { species }\end{array}$ \\
\hline Squirrels & 2 & Not listed & Four species listed \\
\hline Chimpanzee (Pan troglodytes) & Not mentioned & Listed as fully protected & Listed as fully protected species \\
\hline Drill (Mandrillus leucophaeus) & Not mentioned & & \\
\hline Gorilla (Gorilla deihli) & Not mentioned & & \\
\hline
\end{tabular}


a local right, which is strongly engrained in local cultures (Personal communication, forestry expert, November 2016). Some respondents showed concerned about the decrease in wildlife.

"We need to maintain those areas and the animals. The children too should have the opportunity to get to know them. They should be kept for the benefit of the people." (45-year-old male respondent).

There is an absence of local rules and norms, around hunting in the community forest. The predominant (management) strategy is to take as much as one can carry, undiscerning of the species being harvested. One common notion is to hunt the first animal encountered, as it is considered 'bad luck' not to do so. Hunters know where to find certain species, but do not target their hunting efforts towards specific species. Respondents knew and mentioned hunting restrictions in the Afi Mt. wildlife sanctuary and Mbe Mountain community forest, where forest rangers carry out regular patrols and if they encounter hunters they detain and fine these. Respondents also knew that hunting of elephants, gorillas and chimpanzees is prohibited, in line with the forest legislation (CRS 2010). One respondent stated that "if the community gives the bylaws [stricter rules regarding hunting and forest resources use in the community forest], yes, people would accept it" (52-year-old male respondent) provided there is compensation. For instance, "If there are no alternative revenue for a hunting ban then people will hunt" (46-year-old male respondent).

We were particularly interested in hunting of primates and asked respondents if they did hunt drills, chimpanzees or gorillas if they encountered them. The majority stated they would not, but a few respondents said they would (Fig. 4). While respondents refrain from hunting primates partly because of the illegality of it, some also stated that they simply do not possess the weapons needed to take down a large and potentially dangerous primate.

Given the open-access regime of the community forests in the study area it is fundamental to work with local hunters' interests in self-controlling and establishing collective norms and community regulations to limit hunting behavior and effectively support the abundance of species that are more resistant to hunting (Zeckhauser 2017). Thus, from a forest governance perspective, attention should be paid to wildlife management taking into account the social conditions surrounding hunting (Diekert et al. 2016), such as traditions, cultural functions of hunting, beliefs and necessities for providing food for local people (Fischer et al. 2013). Neglecting this undermines effective and equitable forest conservation in the long run, since the disappearance of forest fauna has often unknown cascading ecological impacts (Dirzo et al. 2014).

\section{Design principle 1: clearly defined boundaries}

The community has traditionally and on the basis of customary law exclusive user rights to the community forest, which surrounds the village and borders the Afi River Forest reserve in the west and the Cross River National Park to the east. Based on the interviews and the narrative walks, we found that local respondents relayed the boundaries vaguely dividing the community forest into two parts, a forest reserve and a part dedicated for farming. However, this zoning and the location of these two areas within the community forest are reported differently by the local respondents and are changing. Depending on the respondent, it was unclear what is allowed in terms of land use for agriculture, forest resource collection, timber harvesting and hunting. Some respondents stated that agriculture is prohibited altogether in the so-called reserve part of their community forest. Yet,

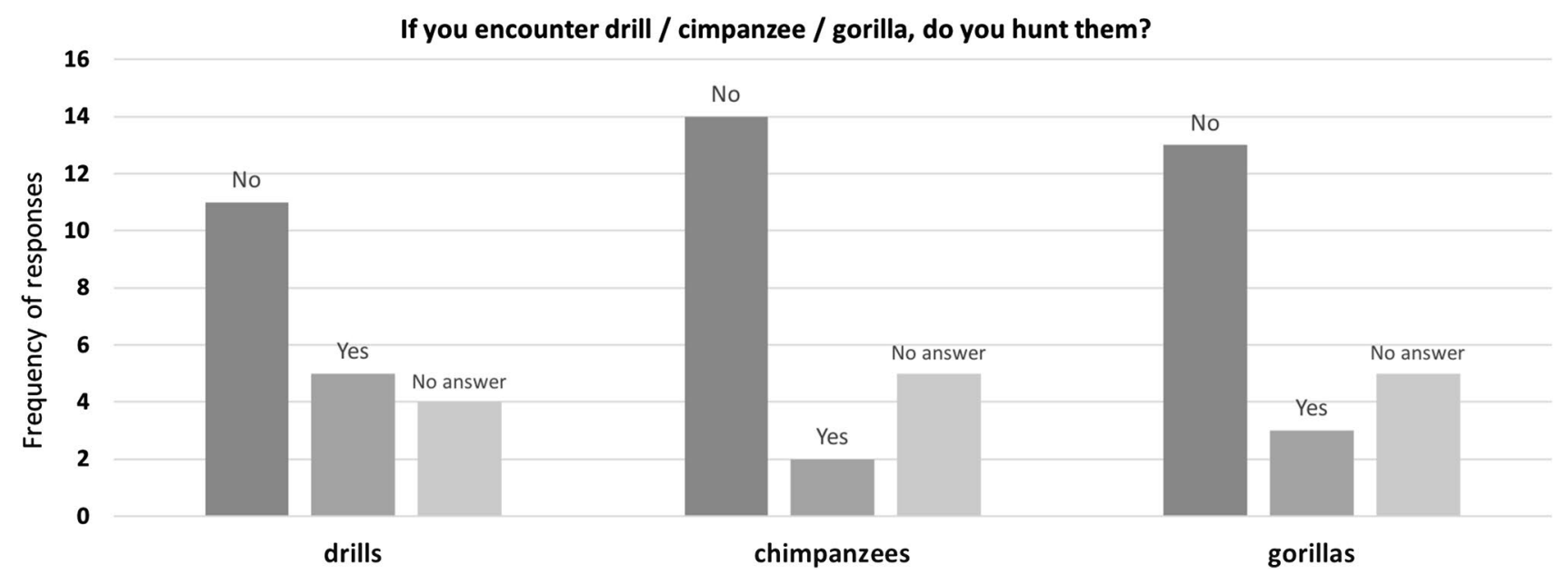

Fig. 4 Respondents answers to the question whether they hunted drills, chimpanzees or gorillas if they were to encounter these in the forest 
during our walks through this forest we observed established farms and recent conversion of forests to fields and cocoa plantations. We asked interviewees about these clearings inside the supposed community forest reserve and some responded that this is against the rules, while others stated it is ok for young famers to clear land to establish their fields. This points towards a lack of cohesion and a tendency for a variable perception of these boundaries amongst local users that demarcate different local rules about resource use inside the community forest. Respondents generally knew about the boundary of their community forest and the Afi river forest reserve, as this is clearly marked by the Afi river (Fig. 5).

\section{Design principle 2: proportional equivalence between benefits and costs}

This principle specifies congruence between costs and benefits and between conservation rules and local social and governance conditions. Before the $2008 \log$ ging ban, a system was in place to distribute royalties from logging in community forests, whereas the community would receive $70 \%$ of the royalties (Amalu et al. 2015). The logging ban was implemented at the same time as CRS emerged as Nigeria's REDD+ pilot state. After the ban, the redistribution of income stemming from established royalty contracts with the CRS Forestry Commission fell through. Any timber was declared illegal and, if encountered, was seized by the newly created ATF. No compensation or alternatives were provided and communities incurred a high cost of losing royalties, seized equipment, confiscated goods, fines and even the imprisonment of 'violators' (Asiyanbi 2016).

At the village level, the costs associated with forest conservation through the logging ban and the declaration of forest reserves are perceived negatively.

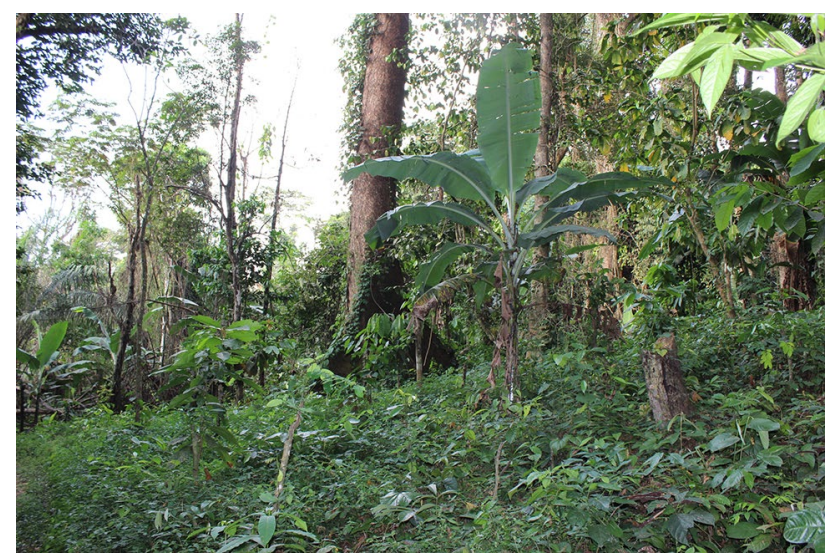

Fig. 5 Recently established agricultural plot in the community forest reserve; photo by Torsten Krause
"The government has protected an area but then they cut in their own area. If young people want to build farms on the cut down area the government stops them" (59-year-old male respondent).

Despite years of REDD+ being presented as a potential income generating activity to forest communities, virtually no benefits have reached the communities around the REDD+ pilot areas. Many respondents feel betrayed by the government.

"No. Nothing comes back to the community. The authorities seize timber, but do not guard the forests" (45-year-old male respondent).

Since forest guards are absent, illegal logging is rife. Furthermore, there is no control of hunting or enforcement of the existing conservation laws by the authorities.

Although some respondents did know about REDD+ they are rather skeptical if it will work.

"I heard of it. It will not work here, people [from the community] will first collect money and then cut trees" (57-year-old male respondent).

The interviews also revealed that since the ban, there is a parallel system to the previous official and legal permit system in place now. External forest loggers circumvent the ban and get unofficial permissions to cut trees in the community forest, typically by paying the chiefs. The same applies to hunting. This highlights the shift from an established official re-distribution to a system that favors elite capture.

\section{Design principle 3: collective-choice arrangements}

Collective-choice arrangements refer to the inclusion of most individuals affected by certain rules into the group that can modify them. In principle, the leadership or village council is constituted by a group of traditional chiefs, often elders representing main families, who are typically male, and an additional public leader who represents the government. The leadership's main function is the general administration of the community, local dispute resolutions and peace settlements, and acting as vehicles for enforcing community discipline as well as enforcing sanctions and compliance to forest management rules (Bisong and Andrew-Essien 2010). The traditional chiefs themselves are users of the forest resources, having farms and engaging in the collection of NTFPs and hunting.

Local norms for species management in the community forest are ambiguous. Timber extraction was previously managed by the forestry commission but to what extent the no-take areas mentioned by respondents are still respected is unsure. 
"No laws on hunting or collecting, if you can carry it you can collect it" (46-year-old male respondent).

"Yes. There are no-take areas for timber and hunting. There are size classes for trees." (45-year-old male respondent).

Regarding local hunting, the interviews revealed very few local rules but a small fraction of respondents referred to the federal and state laws that classified a range species (Nigeria FGo 1985; CRS 2010). For example, respondents mentioned that it is illegal to hunt elephants and gorillas and none of the respondents claimed to hunt gorillas, nor to consume their meat. Yet, most respondents did not know the legal status of less emblematic species (see Table 1 about the legal status of preferred game species).

"The government forbids hunting of monkeys, elephants, pangolins, chimps, drills, alligators; community rules that one cannot sell bushmeat outside the community" (30-year-old male respondent).

However, respondents also mentioned that people from outside the community are restricted from hunting in their community forest, unless they pay a fee or share revenues from the hunt with the community. In the absence of guards or regular monitoring, it is not clear how outsiders are restricted from entering the community forest and from hunting.

Some respondents support the idea of more hunting restrictions. But others had diverging opinions and knowledge regarding collective rules and regulations and disliked hunting restrictions.

"If I were a governor, I would put more species under protection: red deer, duiker, bush pig, all big ones. One should only hunt small ones." (59-year-old male respondent).

"It's not ok to hunt gorillas; in the sanctuary there are laws and you cannot hunt there, otherwise you can hunt all animals" (31-year-old male respondent),

"It's a bad thing that government banned hunting of some species - I would let anyone hunt what they want" (30-year-old male respondent).

\section{Design principle 4: active monitoring}

The interviews revealed that no active monitoring of the community forest area took place in recent years. At the community level, compliance to the state forest law should be monitored via regular patrols and inspections either by state enforcement officers or village council enforcement officers (CRS 2010). Yet, we did not find evidence of an enforcement officer or active monitoring by the community themselves. We observed ongoing and open logging (see Fig. 6), which shows that people do not seem to be too concerned with enforcement. However, the interviews also indicate that before the logging ban was put in place in 2008, local authorities (Forestry Commission) had been more active in monitoring and managing timber extraction.

The state forest law does allow for non-governmental organizations and donor agencies to assist communities in forest monitoring. In adjacent forest reserves, such as the Afi Mountain Wildlife Sanctuary and the Mbe Mountains, community forest monitoring organized by an international conservation organization takes place regularly (Mengnjo 2017). Nevertheless, this is only possible because of continuous external financing for equipment and the salaries of forest rangers from adjacent communities. Yet, at the state level an interview with REDD+ experts at the forestry commission in Calabar in November 2016 confirmed the absence of monitoring in community forests, because of a lack of financial support for monitoring to the community. There are, however, plans to provide stipends for community-based monitoring of forests, biodiversity and other non-carbon benefits as part of future REDD+ implementation.

\section{Design principle 5: graduated sanctions}

To assess principle five-graduated sanctions-we asked interviewees about rules for resources management in place. Respondents generally stated that there are some loose rules regarding the use of the community forest. Most respondents knew that hunting of monkeys, chimpanzees and gorillas is prohibited by law and that there is a ban on logging.

"If someone gets caught hunting apes-government will be called and issue a fine, plus the person will be banned two years from the community" (58-year-old male respondent).

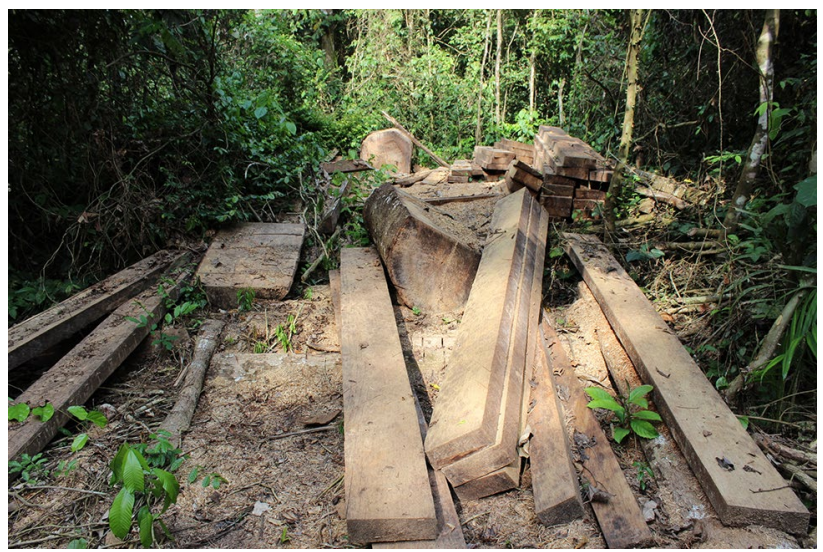

Fig. 6 Logged tree sawn into wood planks in the community forest reserve photo by Torsten Krause 
Nevertheless, answers diverge and some respondents freely mentioned the open-access regime in place allowing hunting without restrictions for community members, not discriminating species or limiting number of individuals that can be harvested.

Respondents mentioned regulations for clearing the forest for farming, logging and timber extraction, but to what extent these rules are enforced is questionable since we observed recently established farms in the protected area of the community forest and various logging activities (Figs. 5, 6). Following this, we enquired whether there are sanctions for violating the rules. Respondents stated that there are sanctions in the form fines for fishing or hunting monkeys in the Afi Mountain Wildlife Sanctuary. However, we did not find evidence to what extent sanctions are enforced, when, and in violation of what rules.

\section{Design principle 6: conflict-resolution mechanisms}

Conflicts over forest resource and land use in protected areas are common in CRS. Since the logging ban was implemented and enforced by the Anti-Deforestation Task Force (ATF), conflicts between community members and the de-facto authority of the task force increased (see design principle 7). Asked about conflicts with institutions and the state authority respondents mentioned first and foremost corruption and the absence of state mechanisms to mediate, leaving forest-dependent communities vulnerable to abuses and capriciousness of powerful groups, i.e., the ATF, who have a mandate from the state governor.

"Corruption is in all levels; rules like stopping farm-

ing affect my livelihood that depends on farming"

(31-year-old male respondent).

Moreover, the conflictive relationship between communities and the enforcement practice of the ATF reveals the difference between policy and practice in the inclusions of fauna conservation in REDD+ processes. The former chair of the ATF is an avid primate conservationist who ensured that anti-poaching and preventing deforestation were at the focus of the enforcement regime.

"We never see the forestry commission in the forest; they even help with deforestation. They cheat and blindfold people." (52-year-old male respondent).

Respondents oftentimes expressed their dislike of the ATF and the logging ban.

"The task force was very aggressive and very activethey acted on information and came and arrested people; the biggest problem is the ban on logging" (67-year-old female respondent).
We found relatively low levels of trust and cooperation among the different forest resource users and towards the forestry commission. Although the ATF has been dismantled, the logging ban is still in place and a newly formed Cross River State green police was created to enforce environmental protection and the logging ban, but subsequently declared illegal by Nigeria's constitutional court. Lastly, in the absence of mediating institutions at the national and state level, there is a risk for new conflicts over resources, particularly given the changes and uncertainty over land tenure and forest carbon rights for local communities, the growing population, and the increasing scarcity of wildlife, timber and land.

\section{Design principle 7: minimal recognition of rights to organize}

Recognized and secured resource rights are important for a more sustainable resource management. However, even with the recognition of a clearly delineated property system one should not assume a more sustainable resource management per se (Ostrom 2009). The level of participation (inclusiveness) of local resource users for collective decisions legitimizes these and supports potentially more equitable outcomes. Nigeria's legal framework gives land tenure over all forest lands to state governors and communities only hold use rights (Asiyanbi et al. 2017). However, according to the Nigerian Forest Law and Regulations from 1956, communities also have rights with regard to resource use within community forests. These include the right to hunt and fish, collect the fruits of specific species, collect snails and tortoises, and to receive royalties on trees felled within their reserves (Amalu et al. 2015).

In anticipation of the implementation of REDD+ in Nigeria, CRS as the pilot state for REDD+ banned logging in 2008. Subsequently, local communities became entangled in 'carbonized exclusion' and saw their rights to forests and forest resources further being undermined (Asiyanbi 2016). Respondents also perceived not to be included and consulted in decision making on forest conservation.

The Anti-deforestation Task Force has the ambition to regain state control over all forest land, including community forests. This led to an alienation of local communities from their forests and inhibited local decision making for forest management together with the forestry commission. It also meant that communities felt they have lost their rights to use forest resources according to established principles with the forestry commission (e.g., royalties) resulting in less forest patrolling and a spike in illegal logging (Asiyanbi 2016).

"When forestry commission was here it was ok, now there is much more logging" (58-year-old male respondent). 
Currently, a major limitation for a more sustainable and locally based natural resource management is the perceived loss of legitimacy of the CRS forestry commission and forest guards among the local population. Since the logging ban, communities lost income from royalties received for timber sourced from communal forests through logging operations managed by the forestry commission (Nuesiri 2017b). Thus, despite the ban's intention to curb deforestation in Cross River, it might have actually led to an increase in deforestation.

"Without the [logging] ban there would have been more forest" (Forestry commission representative, November 2016).

This statement is supported by available Landsat images showing a rise in deforestation from 2013 onwards (GFW 2018).

\section{Design principle 8: nested enterprises-the multi-level legal and political framework}

The legal and political dimensions at national and subnational levels in Nigeria have implications for forest use at the local level. Local resource management is typically embedded in larger contexts and unsustainable levels of resources extraction or land use can and should partly be explained by factors outside of the immediate area in question (Fig. 7). In the context of Nigeria and CRS, we observed that the main pressure on forest lands is the expansion of small-scale cocoa and large-scale oil palm plantations. Local respondents stated that the increase in cocoa prices in the past years has led to a surge in clearing forests for establishing new cocoa farms in the community forest area and beyond.

REDD+ in Nigeria operates through a multi-level institutional structure. In the design and early implementation, local governments and communities have been largely excluded from decision making, underlining the mostly symbolic commitment to local democracy in Nigeria's REDD+ process and exemplified in CRS (Nuesiri 2017a). Many respondents knew about the existence of REDD+ and its meaning.

"The carbon in the forest can be paid for by white men countries money to the government and the government then should pay the community" (31-year-old male respondent).

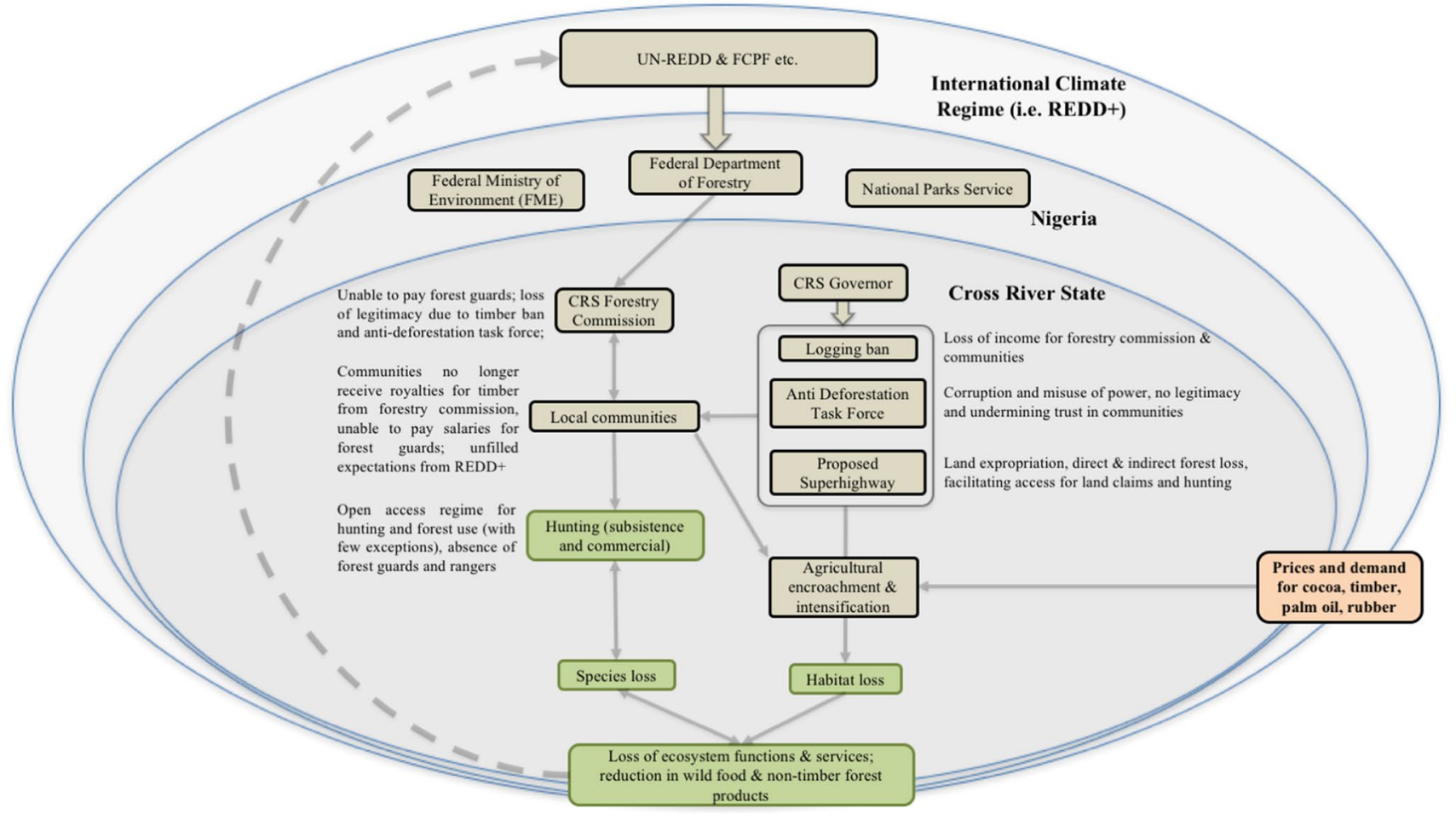

Fig. 7 Visualization of multi-level interactions of REDD+ from the international climate regime in the outer sphere, to the Nigerian and Cross River Context. Arrows represent the one way or two-way rela- tionship that exist. Green boxes represent interactions between human activity and the forest. Prices and demand for cocoa, timber, palm oil and rubber are an external driver of agricultural expansion 
Yet, they are also wary about the government's interference with local forest uses and conservation and the absence of promised benefits.

"What do you provide us with instead? Previously we were promised we would get something from conservation, but they [the government] didn't, so it was not upheld. If we were paid to not hunt or extract timber we would not do it" (52-year-old male respondent).

The responsibility for the management and protection of forests and wildlife in Nigeria is shared between different government organizations at both the federal and state levels. The states exercise control over game reserves, forest reserves and wildlife sanctuaries, while the federal government is responsible for national parks that are administered by the National Park Service [a parastatal under the Federal Ministry of Environment established by the Decree (No. 46) of 1999] (Dunn et al. 2014). All wildlife in national parks is protected by law. State wildlife laws vary greatly, but a law passed provides full protection for Cross River gorillas and all other primates in the state, with strict penalties for violations (Dunn et al. 2014). In CRS, federal and state protected areas and forest reserves, community-managed forestlands and concessions managed by private companies are the main forests management categories (Maukonen et al. 2017).

While national parks are under the jurisdiction of the federal government of Nigeria, all other land is under state jurisdiction according to Nigeria's Land Use Act of 1978. This de facto gives all land to each state's governor and even the 2006 national forest policy defers to the land use act of 1978 on matters of ownership and tenure (Asiyanbi et al. 2017). Confusingly, under Nigeria's customary land tenure systems, forest lands outside forest reserves are said to be owned by communities (Environment FMo 2006). This lack of clarity highlights that land tenure insecurities are commonplace in the forests outside of established national parks and forest reserves. This insecurity of land tenure based on a communal system of land use rights and the open-access regime for forest resources, including hunting, undermines sustainable resource management.

Several interviewees, including representatives from the Forestry Commission stated that the Forestry Commission was regularly patrolling the forest reserves before the logging ban and the ATF. There was much interaction between official forest guards and local communities.

"Before [forest] guards had respect, now they have no respect" (Forestry commission representative, November 2016).

Similarly, local interviews revealed a strong sense of forest guards having been more active before, while now they remain in their office in Calabar and are perceived as being negligent to deforestation and forest degradation.
An important actor was the militarized ATF, set up by the former Governor of Cross River to enforce the logging ban and to show to the world that CRS takes deforestation seriously. Although the ATF enforced the logging ban, seizing large amounts of timber and materials, it had a limited effect on the rate of deforestation as they often confiscate timber rather than preventing logging (Asiyanbi 2016). The detrimental effect of the ATF was also the undermining of local trust in government institutions who are now seen more suspiciously. At the state level, there were tensions between the two sub-national government organizations over their mandates. While the ATF has criticized the forestry commission for being corrupt and ineffective (interview with former ATF chair, 2016), the forestry commission condemned the ATF for being too brutal and undermining its effectiveness, trust and legitimacy in the villages (Forestry Commission representative, 2016).

A 2016 report assessing the policy, legal and regulatory instruments for Nigeria's REDD+ strategy development found among others that grievance mechanisms for local communities are a major area of concern. Further, the report identified the need for a community grown and owned grievance mechanism framework to be introduced into the REDD+ implementation process in Nigeria (Matakala 2016).

\section{Discussion and conclusion}

\section{International level}

Despite being discussed for more than a decade, REDD+ has not really been able to take off and has been termed a conservation fad (Fletcher et al. 2016), creating tremendous expectations amongst local populations, without having delivered the promised benefits. Combined with adverse governmental policies, such as the logging ban and the ATF to oversee and enforce it, the forestry commission charged with managing CRS's forests lost legitimacy and credibility. The example of CRS offers insights into the shortcomings of implementing REDD+ on the ground, particularly in relations to hunting of forest fauna in open-access resource systems as we have evidenced. In addition, representation and participation in forest policies continue to be challenging issues. Furthermore, REDD+ in CRS is challenged by a weak representation from local elected governments (Nuesiri 2017a).

\section{National level}

In CRS, the state governor has power over land use, and can expropriate forest lands without many legal hurdles. 
Relatively, quickly he/she can implement laws that negatively affect local communities, exemplified by the logging ban. The current government of CRS announced in 2016 to construct a superhighway that would connect the state capital Calabar with the northern Benue state. The vision is to turn CRS into an economic powerhouse, with a new deep-sea port, new large garment factories and industrial plantations of oil palm, rubber and teak. This sets forth an agenda of economic development that directly conflicts with the state's ambition to reduce deforestation and maintain the last remaining forest areas, which are increasingly threatened by the very state that maintains a conservation rhetoric publicly.

Nigeria's legal framework acknowledges land tenure rights and allows local users to create their own institution. Furthermore, the revised national policy on the environment supports the development and support of appropriate forest-based development mechanisms in the emerging carbon markets (Article 8) and the integration of economic and social development priorities into forest conservation measures so that local communities can share in the management of the resource and in the benefits of trade in their products (Article 10). However, as we have shown, neither has an appropriate forest-based development mechanism been implemented so far, nor have economic and social development priorities been integrated into forest conservation. Rather, the shared management of resources between local communities and the state via royalties was dismantled. In particular, the logging ban and the subsequent establishment of the Anti-deforestation Task Force have been counterproductive as these did not support a shared management, but rather a top-down militarized enforcement that, ironically, had no evidenced net benefits for the forests of Cross River State nor local social development (Asiyanbi et al. 2017; Enuoh and Bisong 2015). The ban on timber is still in place and effectively puts severe limitations on people's ability to benefit from their forest resources, also restricting using these for own consumption (Asiyanbi 2016).

\section{Local level}

The continuous hunting of threatened species, illegal logging and the encroachment of farms are major challenges in Cross River State's remaining forest areas. Federal and state laws regulating hunting of species (CRS 2010; Nigeria FGo 1985) are not being enforced and knowledge about the species that are included is sparse amongst hunters, who are also unlikely to follow these laws. NGO-led initiatives such as the Mbe Mountain Conservation Association fill conservation voids in CRS through institution building at the local level and the provision of the necessary financial support for maintaining conservation activities together with the adjacent communities. However, apart from hunting, habitat loss leading to fragmentation and separation of the protected areas increasingly isolates the last populations of cross river gorillas, Cameroon-Nigerian chimpanzees, and other threatened species (Dunn et al. 2014). Open-access regimes, a lack of awareness and the high dependence on forest resources are major barriers. Despite more than a decade of REDD+ readiness, preparations, and the promise of carbon money, there is an absence of material benefits from conservation to date and no external incentives to communities for a more sustainable forest use. Under the institutional struggles to channel necessary financing or material support towards forest communities, it is not surprising that there is local discontent and distrust in the government.

We find limited restrictions regarding the products from flora and fauna in the community forest (Bisong and Andrew-Essien 2010), and the unpatrolled forest reserves. Villagers harvest species in an open-access system and outsiders need to get permission and pay to the community for being allowed to hunt in the community forests. Almost no restrictions to limit the number or the species that a hunter can take in the community forest are in place. Our interviews also reveal that people are aware of the illegality of hunting primates. Yet, at the same time it is questionable if they refrain from it because it is illegal or because they lack the appropriate technology and increasing difficulty to encounter primates. The high market value for body parts and meat from great apes continue to represent an incentive for illegal commercial hunting in the region (Tagg et al. 2018). People mentioned sanctions for hunting primates, but we did not find evidence to support that these are enforced, with the exception of the Afi Mountain Wildlife Sanctuary and the Mbe Mountain Community Forest. Yet, it is pertinent to investigate the governance of forest resources and local norms not only in community forests, but also in adjacent forest reserves and protected areas to understand local realities in their entirety.

Preventing further forest loss in CRS is imperative to safeguard the habitat for its native fauna and to continue to provide food and other forest products for the local communities. Not only do the remaining forests of CRS harbor critically endangered primates, they also supply a range of food sources, including animal protein, fruits and nuts, and medicinal plants to local populations. Studies in the northeastern Amazon have found that primary forests provide more game species for harvest than secondary forests per area (Parry et al. 2009); this complements local agricultural production. In Africa, for example, disturbance-tolerant rodents (e.g., cane rats, African brush-tailed porcupine) and some duikers are highly fecund (Fa et al. 1995) and can provide a substantial offtake, even from secondary forest.

Among the most important steps towards a positive future for the critically endangered primates and other wildlife in Cross River State is the strengthening of local institutions for 
the sustainable management of hunting and forest resource use. This includes ensuring a more equitable distribution of benefits from forest resources, REDD+ and other conservation activities, incentivizing more sustainable farming practices on existing agricultural lands and providing alternatives to wild sourced protein.

Acknowledgements We are grateful to many people in Nigeria. First and foremost, the Abo Ebam community for hosting us and agreeing to our interviews, but also to the Cross River State Forestry Commission staff, the Wildlife Conservation Society and others for taking part in the interviews. We are indebted to Edu Effiom and Emmanuel Mbeson, Joy Mbeson and Jacob Enu for helping us and for sharing their many insights about the forest. We gratefully acknowledge funding from the BECC - Biodiversity and Ecosystem services in a Changing Climateresearch initiative and the Swedish Research Council (Grant 201600583, Torsten Krause). We would also like to thank the anonymous reviewers whose constructive comments helped to improve the paper.

Open Access This article is distributed under the terms of the Creative Commons Attribution 4.0 International License (http://creativeco mmons.org/licenses/by/4.0/), which permits unrestricted use, distribution, and reproduction in any medium, provided you give appropriate credit to the original author(s) and the source, provide a link to the Creative Commons license, and indicate if changes were made.

\section{References}

Amalu TE, Ajake AO, Obi PO (2015) Impact of royalties from forest resources on community development in Boki Local Government in Cross River State. Nigeria GeoJ. https://doi.org/10.1007/s1070 8-015-9628-4

Anderies JM, Janssen MA, Ostrom E (2004) A framework to analyze the robustness of social-ecological systems from an institutional perspective. Ecol Soc. https://doi.org/10.5751/es-00610-090118

Andersson Djurfeldt A, Effiom E, Jirström M, Olsson O (2017) Drills and diets, consumption and conservation-the role of primate meat in local diets in and Around Cross River National Park, Nigeria. J Poverty Alleviation Int Dev 8:28

Angelsen A, Brockhaus M, Kanninen M, Sills E, Sunderlin WD, Wertz-Kanounnikoff S (2009) Realising REDD+: National strategy and policy options. CIFOR, Bogor

Asiyanbi AP (2016) A political ecology of REDD+: property rights, militarised protectionism, and carbonised exclusion in Cross River. Geoforum 77:146-156. https://doi.org/10.1016/j.geofo rum.2016.10.016

Asiyanbi A, Arhin A, Isyaku U (2017) REDD+in West Africa: politics of design and implementation in Ghana and Nigeria. Forests 8:78

Baccini A, Walker W, Carvalho L, Farina M, Sulla-Menashe D, Houghton RA (2017) Tropical forests are a net carbon source based on aboveground measurements of gain and loss. Science. https://doi.org/10.1126/science.aam5962

Bello C et al (2015) Defaunation affects carbon storage in tropical forests. Sci Adv. https://doi.org/10.1126/sciadv.1501105

Benítez-López A, Alkemade R, Schipper AM, Ingram DJ, Verweij PA, Eikelboom JAJ, Huijbregts MAJ (2017) The impact of hunting on tropical mammal and bird populations. Science 356:180-183. https://doi.org/10.1126/science.aaj1891

Bergl RA, Warren Y, Nicholas A, Dunn A, Imong I, SunderlandGroves JL, Oates JF (2012) Remote sensing analysis reveals habitat, dispersal corridors and expanded distribution for the critically endangered Cross River gorilla Gorilla gorilla diehli. Oryx 46:278-289. https://doi.org/10.1017/S0030605310001857

Bergl RA, Dunn A, Fowler A, Imong I, Ndeloh D, Nicholas A, Oates JF (2016) Gorilla gorilla ssp. diehli. The IUCN red list of threatened species 2016. http://dx.doi.org/10.2305/IUCN.UK.2016-2.RLTS. T39998A17989492.en. Accessed 14 June 2018

Bisong F, Andrew-Essien E (2010) Indigenous land tenure reforms in the conservation of common property resources in the high forest regions of south-eastern Nigeria. J Sustain Dev 3:12. https://doi. org/10.5539/jsd.v3n4p256

Boissière M, Herold M, Atmadja S, Sheil D (2017) The feasibility of local participation in measuring, reporting and verification (PMRV) for REDD+. PLoS One 12:e0176897. https://doi. org/10.1371/journal.pone.0176897

Boke-Olén N, Abdi AM, Hall O, Lehsten V (2017) High-resolution African population projections from radiative forcing and socioeconomic models, 2000 to 2100. Sci Data 4:160130. https://doi. org/10.1038/sdata.2016.130

Brodie JF (2016) How monkeys sequester carbon. Trends Ecol Evol 31:414-416. https://doi.org/10.1016/j.tree.2016.03.019

Brodie JF (2018) Carbon costs and bushmeat benefits of hunting in tropical forests. Ecol Econ 152:22-26. https://doi.org/10.1016/j. ecolecon.2018.05.028

Corbera E, Schroeder H (2011) Governing and implementing REDD+. Env Sci Policy 14:89-99. https://doi.org/10.1016/j.envsc i.2010.11.002

CRS (2010) A Law to make provisions for the establishment of the State Forestry Commission; and for the purpose of providing sustainable management of the forest and wild life resources, preservation and protection of the ecosystem in Cross River State and other matters connected therewith, vol 3. Calabar

Culot L, Bello C, Batista JLF, do Couto HTZ, Galetti M (2017) Synergistic effects of seed disperser and predator loss on recruitment success and long-term consequences for carbon stocks in tropical rainforests. Sci Rep 7:7662. https://doi.org/10.1038/s41598-01708222-4

Diekert FK, Richter A, Rivrud IM, Mysterud A (2016) How constraints affect the hunter's decision to shoot a deer. Proc Natl Acad Sci 113:14450-14455. https://doi.org/10.1073/pnas.1607685113

Dirzo R, Young HS, Galetti M, Ceballos G, Isaac NJB, Collen B (2014) Defaunation in the Anthropocene. Science 345:401-406. https:// doi.org/10.1126/science.1251817

Dunn A et al (2014) Revised regional action plan for the conservation of the Cross River Gorilla (Gorilla gorilla diehli) 2014-2019. IUCN/SSC Primate Specialist Group and Wildlife Conservation Society, New York

Effiom EO, Nuñez-Iturri G, Smith HG, Ottosson U, Olsson O (2013) Bushmeat hunting changes regeneration of African rainforests. Proc R Soc B Biol Sci. https://doi.org/10.1098/rspb.2013.0246

Enuoh OOO, Bisong FE (2015) Colonial Forest Policies and Tropical Deforestation: the Case of Cross River State, Nigeria Open. J For. https://doi.org/10.4236/ojf.2015.51008

Environment FMo (2006) National forest policy, 2006. Federal Ministry of Environment, Abuja

Ezebilo EE, Mattsson L (2010) Socio-economic benefits of protected areas as perceived by local people around Cross River National Park. Niger For Policy Econ 12:189-193. https://doi.org/10.1016/j.forpo 1.2009.09.019

Fa JE, Juste J, Val Jaime P, Castroviejo J (1995) Impact of market hunting on mammal species in Equatorial Guinea. Conserv Biol 9:11071115. https://doi.org/10.1046/j.1523-1739.1995.951107.x

FAO (2016) The global forest resources assessment 2015. The Food and Agriculture Organization of the United Nations, Rome

Fischer A et al (2013) On the multifunctionality of hunting - an institutional analysis of eight cases from Europe and Africa. J Env Plan Manag 56:531-552. https://doi.org/10.1080/09640568.2012.689615 
Fletcher R, Dressler W, Büscher B, Anderson ZR (2016) Questioning REDD+ and the future of market-based conservation. Conserv Biol 30:673-675. https://doi.org/10.1111/cobi.12680

Galetti M et al (2013) Functional extinction of birds drives rapid evolutionary changes in seed size. Science 340:1086-1090. https://doi. org/10.1126/science. 1233774

GFW (2018) Tree cover loss in Cross River. Global Forest Watch. https:// www.globalforestwatch.org/country/NGA/9. Accessed 20 Oct 2018

Gibson CC, Williams JT, Ostrom E (2005) Local enforcement and better forests. World Dev 33:273-284. https://doi.org/10.1016/j.world dev.2004.07.013

Hinsley A, Entwistle A, Pio DV (2015) Does the long-term success of REDD+ also depend on biodiversity? Oryx 49:216-221. https://doi. org/10.1017/S0030605314000507

Imong I, Kühl HS, Robbins MM, Mundry R (2016) Evaluating the potential effectiveness of alternative management scenarios in ape habitat. Env Conserv FirstView. https://doi.org/10.1017/s03768929150004 17

Krause T, Nielsen TD (2014) The legitimacy of incentive-based conservation and a critical account of social safeguards. Env Sci Policy 41:44-51. https://doi.org/10.1016/j.envsci.2014.04.015

Laurance WF, Campbell MJ, Alamgir M, Mahmoud MI (2017) Road expansion and the fate of Africa's tropical forests. Front Ecol Evol. https://doi.org/10.3389/fevo.2017.00075

Mahmoud MI et al (2017) Alternative routes for a proposed nigerian superhighway to limit damage to rare ecosystems and wildlife tropical conservation. Science 10:1940082917709274. https://doi. org/10.1177/1940082917709274

Matakala PW (2016) National REDD+ framework strategy of the Federal Republic of Nigeria. UNREDD programme \& cross river state. http://www.unredd.net/index.php?option=com_docma $\mathrm{n} \&$ view $=$ download $\&$ alias $=16583$-nigeria-framework-redd-strat egy\&category_slug=national-programme-document-and-related1079\&Itemid $=134$. Accessed 28 Dec 2018

Maukonen P et al (2017) Using spatial analysis to explore multiple benefits from REDD+ actions in Cross River State, Nigeria. Nigeria Natl REDD+ Program, Abuja

Mengnjo C (2017) Afi Mountain wildlife sanctuary annual report 2016. Wildlife Conservation Society Nigeria Program, Calabar

Messier C et al (2015) From management to stewardship: viewing forests as complex adaptive systems in an uncertain world. Conserv Lett 8:368-377. https://doi.org/10.1111/conl.12156

Muller-Landau HC (2007) Predicting the long-term effects of hunting on plant species composition and diversity in tropical forests. Biotropica 39:372-384. https://doi.org/10.1111/j.1744-7429.2007.00290.x

Myers N, Mittermeier RA, Mittermeier CG, Da Fonseca GAB, Kents J (2000) Biodiversity hotspots for conservation priorities. Nature 403:7

Nasi R, Taber A, Vliet NV (2011) Empty forests, empty stomachs? Bushmeat and livelihoods in the Congo and Amazon Basins. Int For Rev 13:355-368. https://doi.org/10.1505/146554811798293872

Nielsen MR, Meilby H, Smith-Hall C, Pouliot M, Treue T (2018) The importance of wild meat in the global south. Ecol Econ 146:696705. https://doi.org/10.1016/j.ecolecon.2017.12.018

Nigeria FGo (1985) Endangered species (Control of International Trade and Traffic) Act. Federal Government of Nigeria, Abuja

Nigeria FGo (2017) National REDD+ process and R-PP implementation-mid-term progress report for Nigeria and request for additional funding from FCPF. Federal Government of Nigeria, Abuja

North D (1990) Institutions, institutional change and economic performance. Cambridge University Press, Cambridge

Nuesiri E (2017a) Feigning democracy: performing representation in the UN-REDD funded Nigeria-REDD programme. Conserv Soc 15:384-399. https://doi.org/10.4103/cs.cs_16_106
Nuesiri EO (2017b) Strength and limitations of conservation NGOs in meeting local needs. In: Larsen PB, Brockington D (eds) The anthropology of conservation NGOs: rethinking the boundaries. Palgrave studies in anthropology of sustainability. Palgrave Macmillan, London, p 289

Ostrom E (1990) Governing the commons - the evolution of institutions for collective action. Political economy of institutions and decisions. Cambridge University Press, Cambridge

Ostrom E (1999) Coping with tragedies of the commons. Ann Rev Political Sci 2:493-535. https://doi.org/10.1146/annurev.polisci.2.1.493

Ostrom E (2009) A general framework for analyzing sustainability of social-ecological systems. Science 325:419-422. https://doi. org/10.1126/science.1172133

Ostrom E, Burger J, Field CB, Norgaard RB, Policansky D (1999) Sustainability-revisiting the commons: local lessons, global challenges. Science 284:278-282. https://doi.org/10.1126/scien ce.284.5412.278

Parry L, Barlow J, Peres CA (2009) Hunting for sustainability in tropical secondary forests. Conserv Biol 23:1270-1280. https://doi.org/10. 1111/j.1523-1739.2009.01224.x

Peres CA, Emilio T, Schietti J, Desmoulière SJM, Levi T (2016) Dispersal limitation induces long-term biomass collapse in overhunted Amazonian forests. J Proc Natl Acad Sci 113:892-897. 10.1073/ pnas. $1516525113 \%$

Skutsch M, Van Laake PE (2008) REDD as multi level governance in the making. Energy Env 19:14

Strassburg B, Turner RK, Fisher B, Schaeffer R, Lovett A (2009) Reducing emissions from deforestation - the "combined incentives" mechanism and empirical simulations. Glob Env Chang 19:265-278. https://doi.org/10.1016/j.gloenvcha.2008.11.004

Sunderland T (2001) Cross river state community forestry project: nontimber forest products advisor. Environmental Resources Management, London

Tagg N et al (2018) A zoo-led study of the great ape bushmeat commodity chain in Cameroon. Int Zoo Yearb 52:182-193. https://doi. org/10.1111/izy. 12175

Thalmann O et al (2011) Historical sampling reveals dramatic demographic changes in western gorilla populations. BMC Evol Biol 11:85. https://doi.org/10.1186/1471-2148-11-85

The IUCN Red List of Threatened Species (2017) International union for the conservation of nature and natural resources. Gland. http://www. iucnredlist.org/. Accessed Aug 2017

UNFCCC (2013) Decision 10/CP.19. Warsaw

UNFCCC (2016) Key decisions relevant for reducing emissions from deforestation and forest degradation in developing countries (REDD $+)$. UNFCCC, Bonn

UN-REDD (2015) Community based redd+ country plan for nigeria. UNREDD and the GEF small grants programme

van Vliet N, Fa J, Nasi R (2015) Managing hunting under uncertainty: from one-off ecological indicators to resilience approaches in assessing the sustainability of bushmeat hunting. Ecol Soc. https://doi. org/10.5751/es-07669-200307

Williamson O (2000) The new institutional economics: taking stock, looking ahead. J Econ Lit 38:595-613. https://doi.org/10.1257/ jel.38.3.595

Zeckhauser R (2017) Human hunters and nonhuman predators: fundamental differences. Proc Natl Acad Sci 114:13-14. https://doi. org/10.1073/pnas.1617003114

Publisher's Note Springer Nature remains neutral with regard to jurisdictional claims in published maps and institutional affiliations. 